\title{
Feasibility Study of Recycled Plastic Waste as Fine Aggregate in Concrete
}

\author{
K. Sai Gopi ${ }^{1}$, Dr. T. Srinivas ${ }^{21}$ and S. P. Raju $\mathrm{V}^{3}$ \\ ${ }^{1} \mathrm{M}$. Tech Structural Engineering Student, GRIET, Hyderabad, India \\ ${ }^{2}$ Professor, Department of Civil Engineering, GRIET, Hyderabad, India \\ ${ }^{3}$ Assistant Professor, Department of Civil Engineering, GRIET, Hyderabad, India
}

\begin{abstract}
Nowadays, Environmental concern towards plastic waste rises because of its low degradability and creating problems like chunking sewer lines, drainages, waterways, filling landfills, health problems, etc. The best approach is recycling and reuses plastic waste. Increase in the production of plastic day by day but, very little was recycled. On the other hand, huge demand for concrete in the construction industry. Utilization of recycled plastic waste in the production of sustainable concrete by partial replacement of fine aggregate. This study has been investigated the utilization of two types of recycled plastic waste Polyethylene Terephthalate (PET) and Polypropylene (PP) as fine aggregate in concrete. M30 grade of concrete has been used by partial replacement of fine aggregate (River Sand) with recycled plastic waste in the percentage of $5,10,15,20$, and 25 . The workability and compressive strength results are checked to find the acceptable percentage of incorporation of PET and PP in concrete. From the results, it is observed that the workability is decreased as the percentage of recycled plastic waste is increased. The Optimum Percentage of replacement of PET is $10 \%$. PP has shown a marginal reduction in compressive strength for $5 \%$ replacement.
\end{abstract}

\footnotetext{
${ }^{1}$ Corresponding Author Email: srinu.tummala@gmail.com
} 


\section{Introduction}

Plastic plays a vital role in developing the economy of the world. Plastics have many uses in human life and many fields such as Health \& Safety, Automobiles, Furniture, Toys, Construction, Electronics, Sports, Agriculture, especially packing industry, etc. The majority of plastics are excellent in thermal, electrical insulation and non-degradable. Plastic materials are used for recycling and it generates a circular economy. Present days expanding the interest for plastic in view of Technological advancements in a wide scope of Consumer and Industrial applications. "Some of the quantity is recycling; remaining is incorporated in landfills, seas, oceans, burnt in municipal dump yards etc., Plastic waste creates air pollution, land pollution, water pollution". "Due to lack of proper waste management for plastic materials, kills numerous animals, Aquatic species etc., And, due to the low degradation rate, it becomes a problem to the environment".

Concrete is one of the building materials which have high demand due to rapid urbanization. "Concrete is made up of natural resource materials such as Sand, Aggregate, Cement". Because of the huge demand for concrete, there is an impact on the depletion of natural resources. "For the Sustainability of natural resources, we want to use alternate materials without affecting the properties of concrete".

Plastics are found in all products. Out of all plastics, Polyethylene Terephthalate (PET) is used for water bottles and Polypropylene (PP) is used for household, Medical devices, etc

The purpose of the study is to evaluate the potential use of alternative materials in concrete, plastic in particular such as PET and PP, as a replacement or supplement for traditional sand as fine aggregate material in concrete for achieving a sustainable environment.

Awham Mohammed Hameed et al (2019) [1] "have reported that, the use of recycled plastic PET as replacement of cement with $(1 \%, 3 \%, 5 \%, 7 \%$, and $10 \%$ ) by weight". The compressive strength, Split tensile strength resulted for $1 \%$ PET increases at $58 \%$, $30 \%$ compared to reference concrete without PET. "The flexure strength resulted for $1 \%$ \& $3 \%$ PET increases at $23 \%, 25 \%$ comparing to reference concrete without PET, the density of concrete decreased with increasing the percentage of PET. He suggested using PET as material in concrete for lower density and cement mortar".

Gerard-Philippe zehil et al (2019) [2] investigates the use of cross linked polyethylene (XLPE) shreds with different sizes such as fine, Medium, large as $2 \%, 4 \%$, $6 \%$ replacement of cement. "The compressive strength and split tensile strength decrease with an increase in the percentage of XLPE and, also those strength decreases with an increase in size of XLPE shreds of same mix, the workability decreases with a marginal reduction to control concrete". The mix containing large size XLPE shreds tends to weaken the concrete skeleton and experienced the largest drop in strength. He concluded that reduction $\mathrm{w} / \mathrm{c}$ ratio efficiently mitigate the strength reduction of XLPE inclusion. "The residual strength of concrete exposure to heat decreases with an increase in XLPE inclusion due to rise in pore pressure by vapors of XLPE which creates micro cracks and weakens concrete mix".

Pooja.P et al (2019) [3] collected milk pouches, polyethylene bags, water bottles and shredded into $4 \mathrm{~mm}-5 \mathrm{~mm}$. "The mixed plastic waste is used $15 \%$, $20 \%, 30 \%$ replacement of fine aggregate in $0.45 \mathrm{w} / \mathrm{c}$ ratio mix". The compressive strength results for $15 \%$, $20 \%$, and $30 \%$ are $20.57 \mathrm{MPa}, 18.57 \mathrm{MPa}, 15.6 \mathrm{MPa}$. And, suggested to use as temporary structures and less load taking structures.

J.Thorneycroft et al (2018) [4] selected four different recycled plastic wastes such as PET, HDPP, HDPE, and PP as replacement of sand in concrete. Eleven different concrete mixes were tested with $10 \%$ replacement of sand. "Five concrete mixes are made with PET fragments such as graded to sand, $0.5 \mathrm{~mm}$ $2 \mathrm{~mm}, 2 \mathrm{~mm}-4 \mathrm{~mm}, 2 \mathrm{~mm}-4 \mathrm{~mm}$ treated with sodium hydroxide and sodium hypochlorite, $2 \mathrm{~mm}-4 \mathrm{~mm}$ treated with sodium hydroxide and sodium hypochlorite and washed". One concrete mix with HDPP such as smooth spherical pellets $3 \mathrm{~mm}$ diameter. One concrete mix with HDPE such as shredded HDPE carrier bags passing through $4 \mathrm{~mm}$ sieve. "Three concrete mixes with PP such as PP strips with aspect ratio 6.7, PP fibers with aspect ratio $400,0.64 \%$ substitution of sand with PP fibers". He concludes that the control of particle size distribution minimizes the change in compressive strength. The compressive strength reduces due to poor bond between plastic and surrounding matrix and suggested to use $10 \%$ PET as replacement of sand by volume in concrete.

Rakesh et al (2018) [5] prepared a mix design for M40 with 30\% fly ash, 20\% GGBS, PET flakes, $0.25 \%$ Recron 3s-fibre. "Five different mixes with $0 \%, 10 \%$, $12 \%, 14 \%, 16 \%$ replacement of PET flakes with sand, the compressive, split tensile, flexure strength decrease with increase in percentage of replacement of PET of sand". For $10 \%$ PET results almost same to reference concrete of $0 \%$ PET. In Sulfuric acid attack test, $10 \%$ PET mix shows less loss in percentage of weight compared to reference concrete mix.

\section{Materials and mix proportion:}

- Ordinary Portland cement 53[IS:8112].

- Coarse aggregate [IS:383 table 2].

- Fine aggregate [IS:383 table 4].

- Chemical admixtures (SNF based) [IS:9103]

- Polyethylene Terephathalate (PET).

- Polypropylene (PP).

\subsection{Polyethylene Terephathalate (PET):}

PET is a Thermoplastic polymer. PET is light weight, Transparent, Strong used for preparing Bottles, Containers, Clothing, etc. It is produced by polymerization of Terephathalic acid and Ethylene Glycol under by product as water. It is taken from recycled industry, which is settled at bottom of washing tank of PET flakes. Size of PET used is less than $1 \mathrm{~mm}$ thin and 2-3mm length.

Table 1 Properties of PET 


\begin{tabular}{|c|c|}
\hline \multicolumn{2}{|c|}{ Properties } \\
\hline Density & $\begin{array}{c}1.38 \mathrm{~g} / \mathrm{cm}^{3}\left(20{ }^{\circ} \mathrm{C}\right) \\
\text { amorphous: } 1.370 \mathrm{~g} / \mathrm{cm}^{3} \\
\text { single crystal: } 1.455 \mathrm{~g} / \mathrm{cm}^{3}\end{array}$ \\
\hline Melting Point & $>250^{\circ} \mathrm{C}$ \\
\hline Boiling Point & $>350{ }^{\circ} \mathrm{C}$ \\
\hline Solubility in water & Practically Insoluble \\
\hline $\begin{array}{c}\text { Specific Gravity of } \\
\text { tested sample }\end{array}$ & 1.47 \\
\hline
\end{tabular}

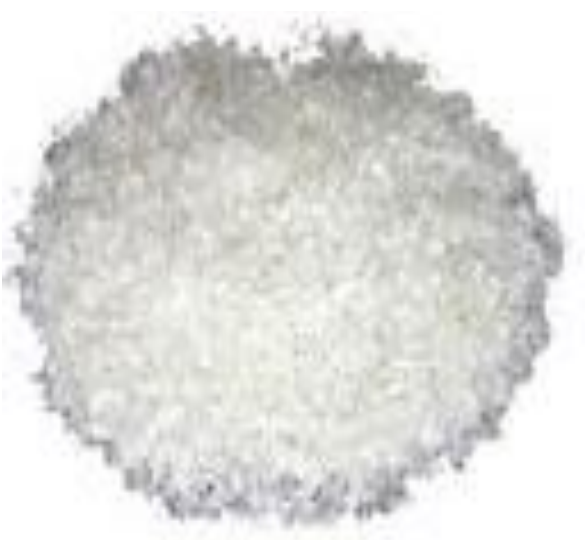

Fig.1: Polyethylene Terephthalate

\subsection{Polypropylene (PP):}

$\mathrm{PP}$ is a Thermoplastic polymer. It is rigid, partially crystalline, more heat resistance, high chemical resistance, lowest density. It is produced by polymerization of monomer propylene. It is taken from recycling industry as grinded form of $2 \mathrm{~mm}-4 \mathrm{~mm}$ size

Table.2 Properties of PP

\begin{tabular}{|c|c|}
\hline \multicolumn{2}{|c|}{ Properties } \\
\hline Density & $0.855 \mathrm{~g} / \mathrm{cm}^{3}$, amorphous \\
& $0.946 \mathrm{~g} / \mathrm{cm}^{3}$, crystalline \\
\hline Melting point & $130-170^{\circ} \mathrm{C}$ \\
\hline Boiling Point & Not applicable \\
\hline Solubility in water & Insoluble \\
\hline $\begin{array}{c}\text { Specific Gravity of tested } \\
\text { sample }\end{array}$ & 0.84 \\
\hline
\end{tabular}

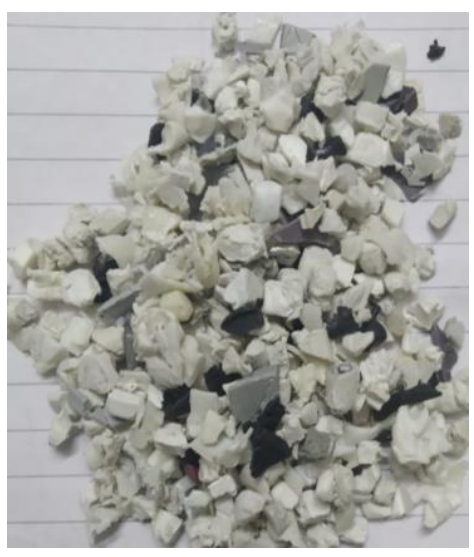

Fig.2: Polypropylene(PP)

\subsection{Mix Design Details}

For M30, Mix design Proportions for $1 \mathrm{~m}^{3}$, $\mathrm{W} / \mathrm{C}$ ratio $=.45$,

Target Compressive Strength $=38.25 \mathrm{MPa}$

Table..3 Mix design details

\begin{tabular}{|c|c|}
\hline Materials & Quantity \\
\hline Cement & $362 \mathrm{~kg}$ \\
\hline Fine aggregate & $682.6 \mathrm{~kg}$ \\
\hline Coarse aggregate & $1184.4 \mathrm{~kg}$ \\
\hline Water & 162.9 litres \\
\hline Admixture (1\%) & 3.62 litres \\
\hline
\end{tabular}

\section{Experiential investigation:}

We casted the concrete cubes of $150 \mathrm{~mm} * 150 \mathrm{~mm} * 150 \mathrm{~mm}$ sizewith different percentages of PET and PP separately by replacement of sand by weight. And, the workability is measured by Slump cone test.

\subsection{Test Results of PET}

Compressive Strength for cubes and Slump values for Normal Concrete by partial replacement of FA with PET:

Table..4 Compression Strength results of PET

\begin{tabular}{|c|c|c|c|}
\hline $\begin{array}{c}\% \text { of PET } \\
\text { replacement } \\
\text { by weight } \\
\text { of FA }\end{array}$ & $\begin{array}{c}3 \text { days } \\
(\mathrm{MPa})\end{array}$ & $\begin{array}{c}7 \text { days } \\
(\mathrm{MPa})\end{array}$ & $\begin{array}{c}28 \text { days } \\
(\mathrm{MPa})\end{array}$ \\
\hline $0 \%$ & 23.5 & 30.7 & 37.8 \\
\hline $5 \%$ & 25.07 & 32.3 & 39.99 \\
\hline $10 \%$ & 24.65 & 30.9 & 38.25 \\
\hline $15 \%$ & 19.125 & 21.7 & 24.225 \\
\hline $20 \%$ & 15.5 & 16.5 & 19.55 \\
\hline $25 \%$ & 11.9 & 14.8 & 14.02 \\
\hline
\end{tabular}

Table..5 Slump Cone test results of PET

\begin{tabular}{|c|c|}
\hline $\begin{array}{c}\% \text { of PET replacement } \\
\text { by weight of FA }\end{array}$ & Slump (mm) \\
\hline $0 \%$ & 110 \\
\hline $5 \%$ & 70 \\
\hline $10 \%$ & 20 \\
\hline $15 \%$ & Zero Slump \\
\hline $20 \%$ & Zero Slump \\
\hline $25 \%$ & \\
\hline
\end{tabular}




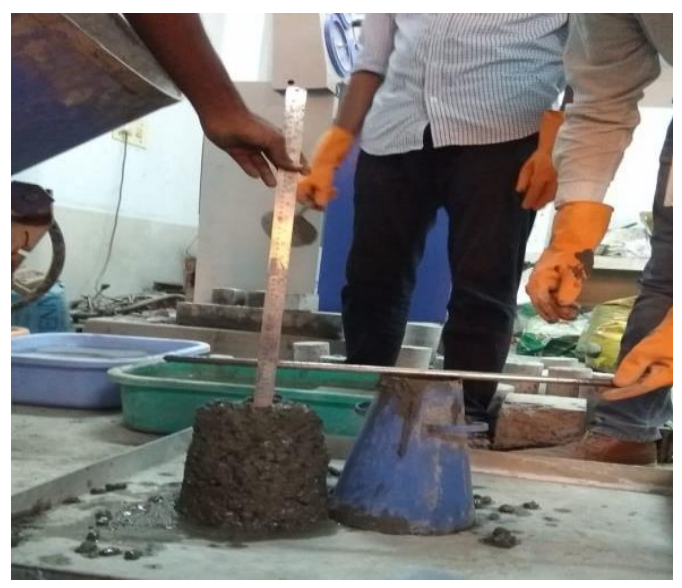

Fig.3: Slump Cone test

The compressive strength values of PET shown in Table.. 4 are decreasing with increase in the percentage of PET. With increase in PET content, the porosity of concrete increases and proper bonding of concrete won't take place due to more amount of PET. Beyond $15 \%$, there are largest drops in compressive strength

The Slump values of PET shown in Table..5 are decreasing with increase in percentage of PET content. With increase in PET content, we obtain the stiff and harsh mix. If we increase the chemical admixture up to a maximum percentage to achieve required workability results the improper mix with bleeding, segregation.

\subsection{Test Results of PP}

Compressive strength and slump values for normal concrete by partial replacement of fine aggregate with PP:

Table.6 Compression Strength results of PP

\begin{tabular}{|c|c|c|c|}
\hline $\begin{array}{c}\text { \% of PP } \\
\text { replacement } \\
\text { by weight } \\
\text { of FA }\end{array}$ & $\begin{array}{c}3 \text { days } \\
(\mathrm{MPa})\end{array}$ & $\begin{array}{c}7 \text { days } \\
(\mathrm{MPa})\end{array}$ & $\begin{array}{c}28 \text { days } \\
(\mathrm{MPa})\end{array}$ \\
\hline $0 \%$ & 23.5 & 30.7 & 37.8 \\
\hline $5 \%$ & 22.1 & 25.92 & 34 \\
\hline $10 \%$ & 21.84 & 24.86 & 28.05 \\
\hline $15 \%$ & 17.85 & 19.12 & 21.25 \\
\hline $20 \%$ & 15.3 & 16.23 & 17 \\
\hline $25 \%$ & 14 & 15.3 & - \\
\hline
\end{tabular}

Table..7 Slump Cone test results of PP

\begin{tabular}{|c|c|}
\hline $\begin{array}{c}\% \text { of PP replacement } \\
\text { by weight of FA }\end{array}$ & Slump (mm) \\
\hline $0 \%$ & 120 \\
\hline $5 \%$ & Shear slump(150) \\
\hline $10 \%$ & Shear Slump(110) \\
\hline $15 \%$ & Shear Slump(130) \\
\hline $20 \%$ & Shear Slump (150) \\
\hline $25 \%$ & \\
\hline
\end{tabular}

The compressive strength values of PP decrease from 5\% replacement of sand with PP due to size and shape of PP Flakes. But, the workability obtained as shear slump along with increase in PP content and admixture content.

Comparing the results of PET and PP; in compressive strength PET has shown better performance up to $10 \%$ replacement of fine aggregate due to PET size is nearer to gradation of sand. In workability, PP has shown slump for all percentages of replacement due to its size. PET has shown slump up to $10 \%$ replacement.

During Compaction, both PET and PP comes out of concrete along with water because of less unit weight compared to all materials in concrete. So, we must take care during tamping without accumulating plastic one place.

\section{Conclusions:}

- The Optimum value for PET is $10 \%$ replacement of Fine aggregate. It is used for all structural works with proper care during mixing.

- $\quad$ PET is used as replacement of Fine aggregate in mass concrete where degree of workability is medium and low.

- $\quad$ PP of $2 \mathrm{~mm}-4 \mathrm{~mm}$ size is used as replacement of fine aggregate in non-structural works by keeping the loss of strength.

- Water absorption and Porosity increases with increase in the percentage of PET and PP content.

- The density of concrete decrease with increase in PET and PP content because the unit weights of PET and PP less than the unit weight of sand.

\section{References}

1. Awham Mohammed Hameed ${ }^{1}$, Bilal Abdul-Fatah $\mathrm{Ahmed}^{2}$, "Empolyment the plastic waste to produce 
the light weight concrete", Energy Procedia, Volume 157, Pages 30-38, ( January 2019).

2. Gerard-Philippe Zehil ${ }^{1}$, Joseph J. Assad ${ }^{2}$," Feasibility of concrete mixtures containing crosslinked polyethylene waste materials", Construction and Building Materials, Volume 226, (30 November 2019), Pages 1-10.

3. P.Pooja ${ }^{1}$, Manendra Vaitla ${ }^{2}$, Gudapati Sravan ${ }^{3}$, Mt.Purusotham Reddy ${ }^{4}$, M.Bhagyawati ${ }^{5}$," Study on Behavior of Concrete with Partial Replacement of Fine Aggregate with Waste Plastics", Volume 8(2019), Pages 182-187.

4. Naspuri Arun Raju, T. Suresh Kumar, International Journal of Innovative Technology and Exploring Engineering, Vol. 8 no. 11, pp: 3860-3864, (2019)

5. Rakesh ${ }^{1}$ Siddharth $B^{2}$, Maneeth $P$ $\mathrm{D}^{3}$,Shreenivasreddy $\quad \mathrm{S}^{4}$,,$\quad$ Experimental Investigation on Concrete using waste materials as fly ash, GGBS, PET flakes, and fibres", International Journal of Management, IT \& Engineering, Volume 8, (August 2018).

6. Sateesh, N., Sampath Rao, P., Ravishanker, D.V., Satyanarayana, K., "Effect of Moisture on GFRP Composite Materials", Materials Today: Proceedings, 2 (4-5), pp. 2902-2908, (2015).

7. Naidu, K.S.S.T., Rao, M.V.S., Reddy, V.S, "Microstructural characterization of calcite mineral precipitation in bacteria incorporated concrete", IJITEE, 8 (9 Special Issue 2), pp 641-642 (2019).

8. Satyanarayana, G.V.V., Saikiran, C.H, "Effect on mechanical properties of M35 grade concrete by partial replacement of fine aggregate with copper slag”, IJITEE, 8 (12), pp 3759-3762.

9. Mallikarjuna Reddy, V., Praveen, R., " Effect of polyethylene glycol in self-curing of self compacting concrete", IJRTE, 8 (3), pp. 7280-7283 